\title{
RELEVANCE OF INDIGENOUS KNOWLEDGE SYSTEM OF THE TRIBES OF ARUNACHAL PRADESH IN CORONA PANDEMIC - AN ANTHROPOLOGICAL APPROACH
}

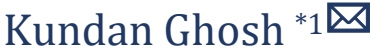 \\ ${ }^{1}$ Assistant Professor, Depatrment of Anthropology, Mahishadal Girls' College, Rangibasan, Purba \\ Medinipur, West Bengal
}

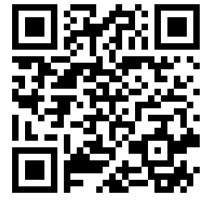

DOI: https://doi.org/10.29121/granthaalayah.v8.i5.2020.204

Article Type: Research Article

Article Citation: Kundan Ghosh. (2020). RELEVANCE OF INDIGENOUS KNOWLEDGE SYSTEM OF THE TRIBES OF ARUNACHAL PRADESH IN CORONA PANDEMIC AN ANTHROPOLOGICAL

APPROACH. International Journal of Research -GRANTHAALAYAH, 8(5), 241-245.

https://doi.org/10.29121/granthaa layah.v8.i5.2020.204

Received Date: 15 May 2020

Accepted Date: 31 May 2020

Keywords:

Indigenous Knowledge System

Pandemic

Self- Resilience

Quarantine

\begin{abstract}
People across various societies in India including tribal societies are faces crisis created by Covid-19 and try to find out how they can encounter it. The present study was undertaken to explore the association of Indigenous Knowledge System with quarantine and lockdown process emerged due to Covid- 19. For this present study, three tribes were selected from Tani tribal groups (Galo, Adi and Nyishi) of Arunachal Pradesh, who performed customary quarantine rituals. This study is based on secondary sources of data. It is noticed that their ritualistic quarantine beside small scale society, bonding and solidarity play a crucial role to fight with Corona. These tribal groups their revived traditional ritual practices and adopted self - resilience strategies to cope up with Corona pandemic.
\end{abstract}

\section{INTRODUCTION}

Anthropology has always been interested in knowing different cultural aspects of different societies. Each culture has its ecological set up and historical background. The approach of cultural relativism has advocated the field workers to collect data out of field by preceding local people's view point. Due to ongoing Covid-19 pandemic the whole country has been in lockdown since $24^{\text {th }}$ of March, 2020 and when the author writes this article, it became 58 days lockdown and total confirmed case in India is 111601 (www.covid19india.org). Now we look at our study context i.e. Arunachal Pradesh. A 31-year man from Medo village in Lohit district of Arunachal Pradesh, was the first case of corona virus in state, who attended a congregation in Delhi's Nizamuddin West. He is recovered on $16^{\text {th }}$ April, 2020 and since then no other cases are notified in the state. So, automatically the question is raised what kind of strategies help the people of Arunachal Pradesh specially tribal people from spreading the virus in large scale. 
Relevance of Indigenous Knowledge System of The Tribes of Arunachal Pradesh in Corona Pandemic - An Anthropological Approach

\section{OBJECTIVE OF STUDY}

Main objectives of this paper are twofold- (i) How tribal quarantine rituals helped Arunachal Pradesh become Covid-19 free? And (ii) How tribal revived the indigenous lockdown practice or isolation rituals to fight against pandemic?

\section{METHODOLOGY}

This paper is based on the secondary data collected from different sources like internet, research articles and newspaper articles.

\section{THE STUDY AREA}

Arunachal Pradesh is one of the seven North Eastern states of India. This state bordering Bhutan in the west, Tibet in the north-west, Myanmar in the east and China in the north. It is located between $26^{\circ} 28^{\prime}-29^{\circ} 30^{\prime} \mathrm{N}$ Latitude and $91^{\circ} 30^{\prime}-97^{\circ} 30^{\prime}$ E Longitude. Total population of Arunachal Pradesh is 13.84 lakhs (Census of India, 2011) and is scattered over 16 districts. There are total 26 major tribes reside in Arunachal Pradesh. The major tribes are Galo, Adi, Nyishi, Aka, Minyong, Apatani, Bugun, Tagin, Miji, Tangsa, Khamti, Wancho, Sherdukpen, Monpa, Memba, Mishmi etc. The tribes have their own distinct cultural identities which makes them unique in their own way. It is observed that, during the Corona pandemic tribes of Arunachal Pradesh practicing an equivalent system of ritualistic lockdown. These tribal groups in Arunachal Pradesh had implemented their own customary rituals which are equivalent to a lockdown, much before the lone Covid-19 case was reported in the state. These rituals resolve around the concept of self-quarantine.
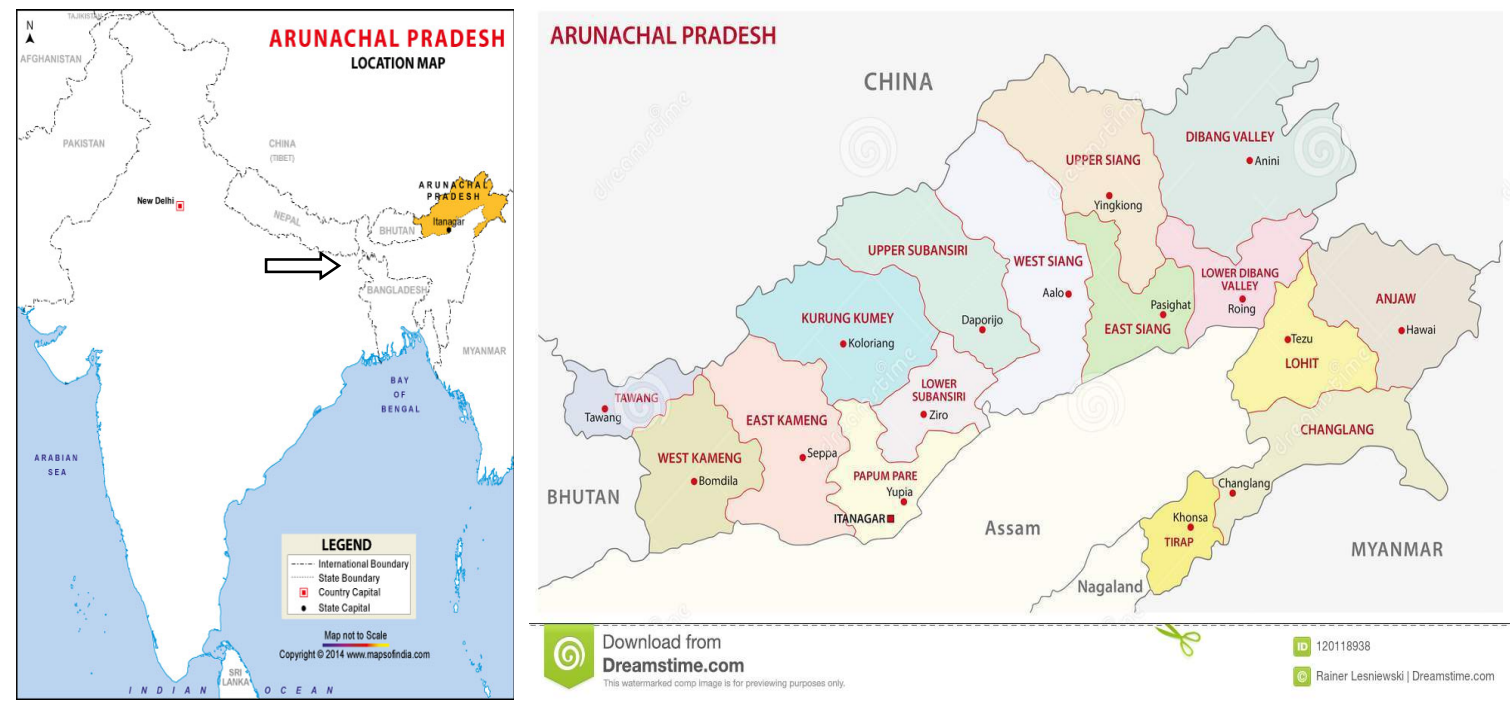

Map of India showing Arunachal Pradesh (left, source- mapsofindia.com) and Map of Arunachal Pradesh showing major districts division (right, source- Dreamstime.com)

The People- Galo, Adi \& Nyishi: For this present study, three tribes were selected from Tani tribal groups (Galo, Adi and Nyishi), who performed customary quarantine rituals. Galo people are found primarily in West Siang, southwestern side of East Siang, southeastern side of Upper Subansiri and small pockets in Lower Dibang valley and Changlang district of Arunachal Pradesh. Galo is numerical dominate in West Siang district. Out of 21 circles in district Galo occupied in 13 circles (Lombi, 2016). The Galos belong to the Tani group inhabiting Assam and Arunachal Pradesh, beside Tibet. Galo community has been recognized as schedule tribe in the Amendment to the Constitution Order, 1950, Part-XVIII. According to 2011 census total Galo population is 1.3 lakhs. The Galos speak Galo dialect which is a branch of Tibeto-Burman language. Their main subsistence includes shifting cultivation and animal husbandry. Apart from that they hunt games, trap birds, fish and gather wild foods. Galo are normally 
monogamous, but polygamy also practiced by affluent people as a sign of their prosperity and prestige. The village council is called Keba with appointed headmen and village elders as member looking after the overall administration of the village. Their main festival is Mopin festival, they celebrated it in the month of April every year. They celebrate it to ward off evil spirits that bring bad luck to the community. They pray during this festival so that natural calamity of any type does not hit them. They believe that doing this allows them to live their lives peacefully. The Galos perform Popir dance.

Adi community reside in the far north inhabiting East Siang and Lower Dibang Vally district of Arunachal Pradesh. Ethnolinguistically they belong to Tibeto-Burman language speaking population. They are experts of making cane and bamboo products.

Nyishi is the single largest tribe of Arunachal Pradesh. They support themselves with slash and burn agriculture and with hunting and fishing. They speak Tibeto- Burman language of the Sino - Tibetan family.

They live in harmony with nature. They are known for craftsmanship and cleanliness. Their villages are neat and clean. They have their own worldview. Community base cultural practice and active participation prevalent among them. As they are small scale society, bonding and solidarity is strong among them, its play a crucial role to fight with Corona. The practice of staying in quarantine and maintaining the quarantine rules religiously is ingrained in the society in Arunachal Pradesh.

Arr-Rinam \& Ali- Ternam - isolation rituals of Galo: Galo tribe performed Ali- Ternam, (Ali means epidemic and Ternam means forestall or prevent) a customary lockdown, to crub the spread of infections. It is a ritual practiced by the Galo community since time immemorial during times of epidemic. So, it is a ritual to protect the whole community against the epidemic or in other words to prevent the epidemic to occur.

Arr-Rinam is the Galo equivalent of lockdown imposed by consensus for 48 hours whenever an epidemic strike. Arr-Rinam, which follows the Ali-Ternam ritual to ward off an epidemic, has part of their culture. This ritual is done in times of calamities including epidemics that inflict animals. These rituals have been performed periodically for livestock, primarily the semi- wild animal Mithun, that are prone to contagious diseases. Galo people lastly performed these rituals four decades ago when a water -borne disease had affected many members of the community. Now in 2020 during Corona pandemic they performed the rituals again for the safety of humans.

They performed rituals under the guidance of a shaman (Nyibo), by the priest called Bos. In case of Aalo, West Siang district local priest Mogi Ori perform all the rituals and chant prayers. The lockdown begins with the "reading of the liver of chickens"- a ritual called "haruspicy". It performed by a shaman.

They lockdown themselves whenever an epidemic strike. These traditional lockdowns involve barricading villages with bamboo gates and sacrificing certain animals. In areas where the Galo people live, villagers implemented Ali-Ternam- this prohibits the entry and exit of people into and from the villages two days after it begins. Several other villages were also seen blocking their entry points with tree logs and bamboos while some are reportedly not even allowing their kith and kin, especially those coming from other parts of the country to directly enter the villages unless properly quarantined. There would be restriction in all kind of movements.

The ritual ends with the community leaders sealing five major entry points of the district. All the five different entry points of the district- Gabu near Logum Jini, Patum near Biru, Piggo near Keak, Hill Geko near Nyorak and Essi Tamen - would be sealed completely and the people have been urged to cooperate with the society for successful conduct of the ritual. By doing this they lockdown villages for a few days to stop spread of Corona virus pandemic.

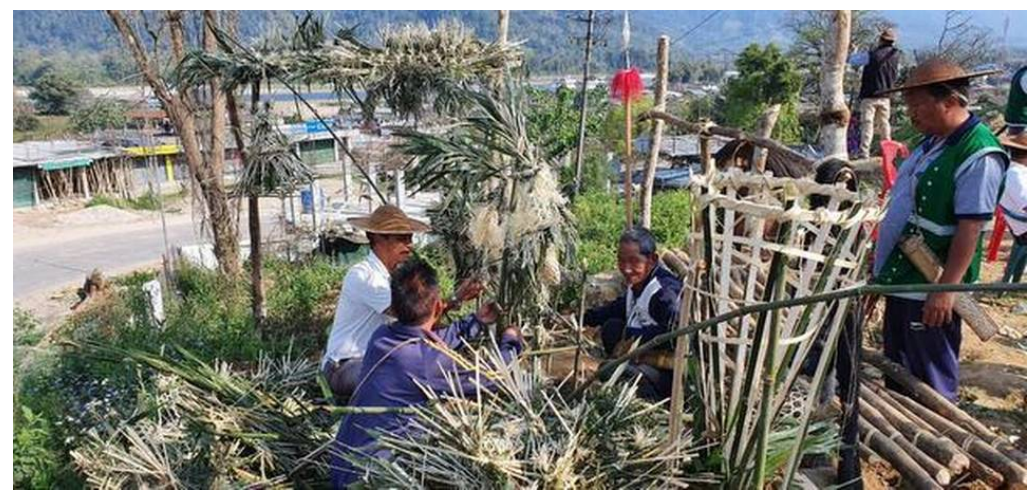

Getting prepared for rituals (Photo: Rahul Karmakar, The Hindu, 28.3.20) 


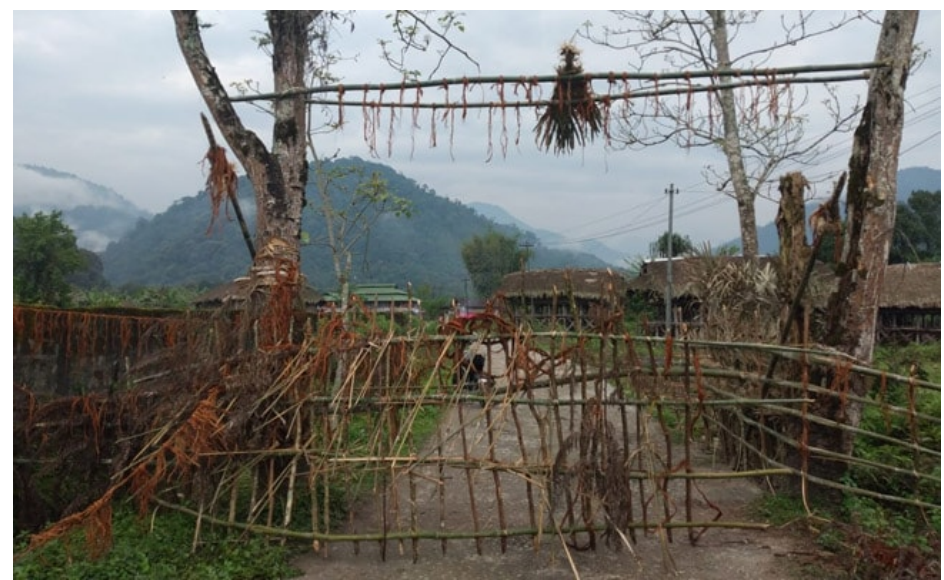

Blocking their village entry points (Photo- Bamdo Kamki)

Motor and Arrue - isolation rituals of Adi \& Nyishi: The Adi and Nyishi tribes observed rituals called Motor and Arrue, respectively. Adi community of East Siang and Lower Dibang Vally district of Arunachal Pradesh, also performed a similar ritual called Motor. They share a system of belief that within this period of restriction the shamans (religious priest) derived a legendary power to locate wild herbs and prepare medicines out of it which could help them to combat an epidemic. Here is the importance of ethno-medicine has been raised, which is an integral part of the discipline of Anthropology. The Adis construct gates at the entrance point of villages as a method of warding off epidemics and evil spirits. No person is allowed to enter or leave the villages. Nyishi community of Pspum Pare and East Kameng district of Arunachal Pradesh observed Arrue involving self- quarantine. Their religion involves belief in spirits associated with nature.

\section{CONCLUSION}

From the above discussion it is found that social distancing is aided by age-old rituals in Arunachal Pradesh. These tribal groups adopted self - resilience strategies to cope up with Corona pandemic. They have revived their indigenous lockdown practice or isolation rituals. Science has a greater impact on us since ages, but the importance of traditional knowledge cannot be ignored. Societies and different communities have always shown instances of traditional practices which carry an importance scientific background. In future there is more scope to know these rituals from empathic understanding and emic pint of view

\section{SOURCES OF FUNDING}

None.

\section{CONFLICT OF INTEREST}

None.

\section{ACKNOWLEDGMENT}

None.

\section{REFERENCES}

[1] Lombi, Shri Pakngu 2016 People's perception about shifting cultivation - with special reference to the Galo tribe of West Siang District, Arunachal Pradesh (India). International Journal of Scientific and Research Publications, Vol.6, Issue 7 p.454 
[2] www.google.com/amp/s/www.sentinelassam.com/amp/editorial/an-anthropological-approach-tolockdown

[3] https://www.thehindu.com/news/national/other-states/arunachals-tribes-revive-indigenous-lockdownrituals/article31186665.ece

[4] https://www.magzter.com/article/Newspaper/The-Hindu/Arunachal-Pradesh-Tribes-Revive-IndigenousLockdown-Rituals

[5] https://www.ndtv.com/india-news/coronavirus-india-how-indigenous-quarantine-rituals-helpedarunachal-become-covid-free-2215932

[6] www.covid19india.org accessed on 20.05 .2020 at $9 \mathrm{pm}$. 